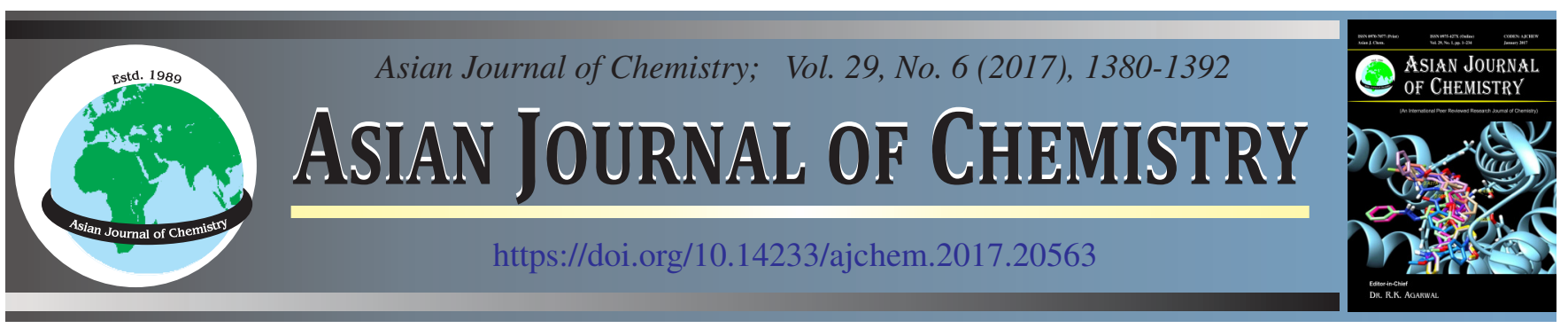

\title{
Optimization of Flaked Rice Dry Roasting in Common Salt and Studies on Associated Changes in Chemical, Nutritional, Optical, Physical, Rheological and Textural Attributes
}

\author{
Shiv Kumar and K. Prasad*
}

Department of Food Engineering and Technology, Sant Longowal Institute of Engineering and Technology, Longowal-148 106, India

*Corresponding author: E-mail: profkprasad@gmail.com

Received: 2 February 2017;

Accepted: 13 March 2017;

Published online: 10 April 2017;

AJC-18359

\begin{abstract}
Flaked rice (Avalakki, Atakulu, Poha, Chirwa) is a flattened carbohydrate rich edible food obtained on processing of paddy (Oryza sativa L). It is considered to be more nutritious as compared to polished white rice. Flaked rice is a common breakfast item in Indian sub continent and consumed as either sweet or salty snacks item mostly in its fried or roasted forms. Traditionally prepared sand roasted flaked rice is associated with the problem of residual sand. Roasting in common salt as a conduction medium thus proved to be the suitable alternative. Dry roasting of flaked rice is thus performed at precisely controlled temperature in a developed agitated dry roaster in the temperature range of 260 to $340{ }^{\circ} \mathrm{C}$ with a scientifically designed combination as per central composite rotatable design combination with time ranging from 20 to $60 \mathrm{~s}$. The effect of roasting temperature and time on selected physico-chemical, optical and sensory characteristics were observed. Results indicated that roasting temperature and time have significant effect $(\mathrm{p} \leq 0.05)$ on studied parameter i.e. whiteness index, yellowness index, hardness, expansion ratio, hydroxyl methylfurfural and overall acceptability. The temperature and time combination of $302{ }^{\circ} \mathrm{C}$ and $41 \mathrm{~s}$, respectively yield most liked roasted rice flakes.
\end{abstract}

Keywords: Paddy, Roasting, Roasted flaked rice, Processing, Optimization.

\section{INTRODUCTION}

India is a leading paddy (Oryza sativa L.) producing country with a production of 157.20 MMT in the year 2014-15 from the crop area of 43.40 million hectare [1]. The contribution of India towards world paddy production is one fifth with a consolidated production figures of $22.69 \pm 1.79 \%$ and $20.71 \pm 1.64 \%$ for Asia and world, respectively. The trends of changes in the crop area and production figures for the paddy in India in comparison to the Asia and the world are depicted in Figs. 1 and 2. Asian countries produce more than $90 \%$ paddy produced in the world. The edible monocotyledon, the starchy kernel obtained as rice from the processing of paddy available in abundance becomes a common staple food item of Asian people. Rice being a common food item of the region, therefore, rice based various ready to eat food relishes are produced locally at small or home scale levels [2-5]. Importance of physical properties in designing various food processing equipments for the purpose of harvesting, threshing, drying, handling, conveying, storage and aeration are very well recognized [6,7]. Our research on different characteristics of paddy to rice are reported elsewhere but associated research data for the development of technologies related to the mass productions of various rice based products are still lacking and not readily available [8-16].
After harvesting, the paddy cannot be directly consumed by human being due to the presence of non-edible covering on rice [17]. Paddy kernel, seed or rice as protected by the presence of outer protective coverings, the husk contributes $18.74 \pm 0.28 \%$ of the total weight of paddy used as fuel in operating the boilers [11]. Brown peripheral layer beneath the husk and on the surface of kernel known as bran layer imparts $6.43 \pm 0.87 \%$ of paddy. The bran layer which is rich in oil, protein, vitamins and minerals, lost during milling or polishing and basically used for the preparation of rice bran oil [18]. About $50 \%$ of vitamin B-complex is thus found to be eliminated during milling [19]. The kernel having germ portion approximately $1.71 \pm 0.52 \%$ and remaining part $74.76 \pm 0.98$ $\%$ of kernel is the endosperm. Endosperm which is the leading portion of rice basically made up of starch and protein [20,21]. Rice is often consumed in the form of white rice (polished rice) or brown rice in the form of raw or parboiled rice after cooking [22]. Rice as an ingredient being gluten free can be used as best substitute for the development of foods for patients' suffering from celiac disease [4,5].

Flaked rice (Avalakki, Atakulu, Poha, Chirwa), puffed or expanded rice (Puri, Burugalu, Muri, Murmura) and popped rice (Nel Puri, Aralu, Kheel) are the important pre-cooked rice products. Flaked rice is obtained after soaking, roasting and 


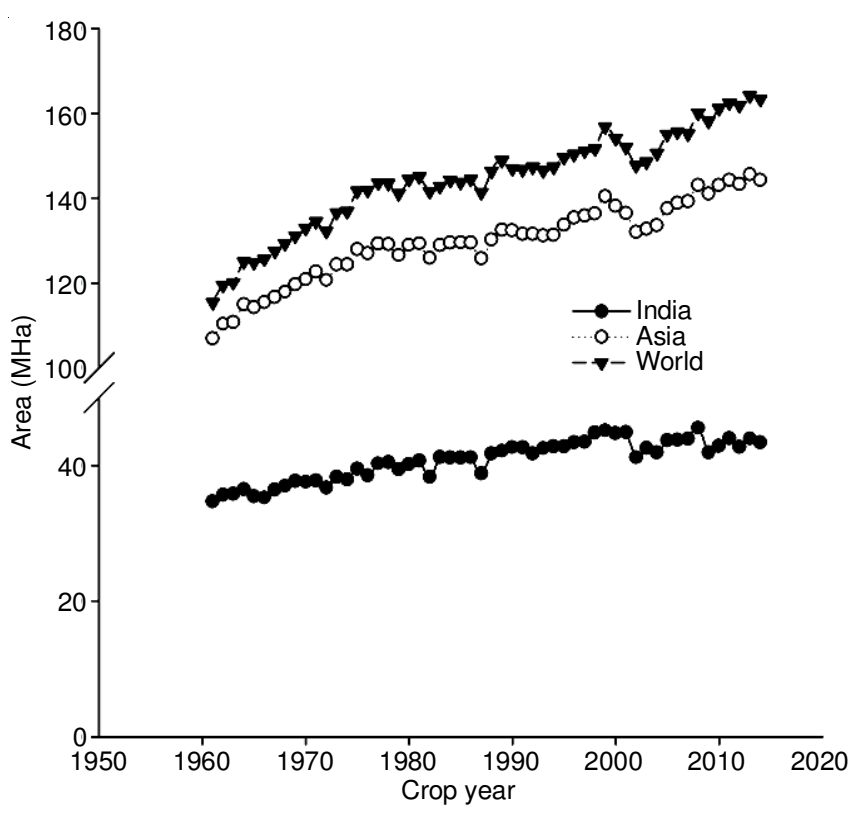

Fig. 1. Comparative trends in the cultivated area under paddy production

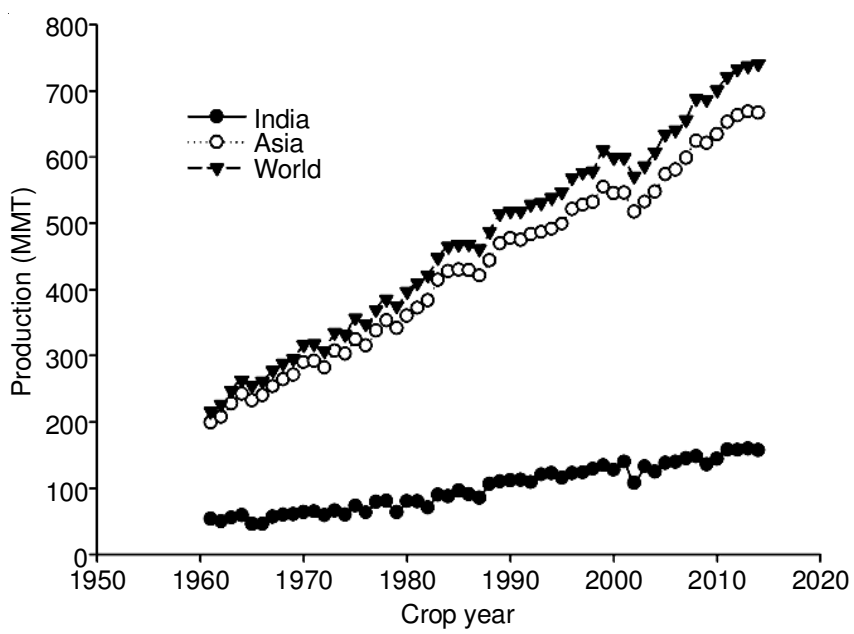

Fig. 2. Comparative trends in the production pattern of paddy

flaking process of paddy to variable thickness [23,24]. Flaked rice is having high dietary fiber, minerals and oryzanol content than milled rice [25] mainly responsible for providing benefits of reduction in blood cholesterol, coronary heart diseases (CHD) and celiac disease. Water soaked flaked rice is consumed either after adding of sugar and mixing with small amount butter oil or after adding the salt and chopped wet onion, chilly and mixed with mustard oil. Also, it is consumed in sweetened form after addition of curd or milk with banana as common breakfast item; also it is consumed in this form, which is found to be linked as ritual and traditional belief system of celebrating an important Sankrant festival in India. Further, the puffed rice and roasted flaked rice are very popular rice based breakfast or snacks items, which are widely consumed in the major part of Asian countries especially in India $[26,27]$. Flaked rice is partially cooked and having gelatinized starch granule is either roasted or fried for its use in the development of various snacks.

Roasting is one of the traditional cooking method comprising high temperature and short time heat exposure having some roasting medium like sand. Common salt as heat transfer medium or sometimes direct pan roasting is also carried out. During roasting starch granules are gelatinized therefore, a part of it is retrograded, which ultimately transform into resistant starch. These resistant starches thus act as a source of dietary fiber, lower blood cholesterol level, glycemic index (GI) and ultimately controls diabetes. This resistance starch as prebiotic helps in maintaining gut health to prevent the risk for the onset of colon cancer. Starch digestibility after dry heat parboiling and flaking flowed by roasting reduces glycemic index [28,29]. Flaked rice and parboiled rice has been reported to be having lower glycemic index than raw rice. Roasted flaked rice and puffed rice may further increases the dietary fiber and pass the digestive tract to be considered as pre-biotic foods $[27,30]$. The roasting of flaked rice in sand leads to the residual portion of it in final product. Thus, the aim of present study was to find out the optimum roasting time and temperature of roasting medium as salt to investigate the associated changes in properties of flaked rice on roasting.

\section{EXPERIMENTAL}

The Gurjari paddy variety procured from Anand Agriculture University (Gujarat) was used in the present research work.

Preparation of flaked rice: Flaked rice was manufactured at Balatripura Agro Industries, Ahmadabad, India. Process flow diagram for the development of flaked rice is depicted (Fig. 3). Raw paddy was soaked in water for 7-8 h at room temperature to attain moisture content of soaked paddy to near $30 \pm 2 \%$. This was followed by removal of water by draining the water from soaking tank then the soaked paddy was conveyed using bucket elevator to roaster with a roller speed of $13 \mathrm{rpm}$ by the use of $5 \mathrm{HP}$ electrical motor operated in such a higher temperature environment for a short period of time in fine hot sand maintained at the temperature range of 178-180 ${ }^{\circ} \mathrm{C}$ for $28 \mathrm{~s}$. Roasting process of soaked paddy thus results in the dried husk with the internal moisture content of the kernel in the range of $17-20 \%$. Without any delay the roasted paddy was conveyed to the flaking machine the edge runner operating at $900 \mathrm{rpm}$ operated by a $15 \mathrm{HP}$ electrical motor. The obtained flaked rice was further cleaned in a cleaning machine to separate the broken and fines and the resulted flaked rice having the physico-chemical characteristics as given in Tables 1 and 2 , was stored at refrigerated temperature in air tight container till its further use.

\begin{tabular}{lcc}
\multicolumn{3}{c}{ TABLE-1 } \\
CHEMICAL COMPOSITION ON \\
\multicolumn{2}{c}{ TRANSFORMATION TO ROASTED FLAKED RICE } \\
\hline Chemical parameters & Flaked rice & Roasted flaked rice \\
\hline Moisture content $(\%)$ & $9.97 \pm 0.13$ & $4.58 \pm 0.04$ \\
Total ash $(\%)$ & $1.60 \pm 0.20$ & $1.93 \pm 0.03$ \\
Fat $(\%)$ & $3.09 \pm 0.14$ & $2.65 \pm 0.16$ \\
Protein $(\mathrm{g} / 100 \mathrm{~g})$ & $6.06 \pm 0.17$ & $6.02 \pm 0.18$ \\
Crude fiber $(\mathrm{g} / 100 \mathrm{~g})$ & $1.54 \pm 0.05$ & $1.74 \pm 0.09$ \\
Starch $(\%)$ & $79.22 \pm 0.89$ & $77.58 \pm 0.82$ \\
Amylose $(\%)$ & $19.66 \pm 0.33$ & $20.60 \pm 0.72$ \\
Resistant starch $(\%)$ & $1.62 \pm 0.09$ & $2.55 \pm 0.11$ \\
\hline Values represented as Mean \pm Standard deviation \\
\hline
\end{tabular}




\begin{tabular}{|c|c|c|}
\hline \multicolumn{3}{|c|}{$\begin{array}{c}\text { TABLE-2 } \\
\text { PHYSICAL PROPERTIES ON } \\
\text { TRANSFORMATION TO ROASTED FLAKED RICE }\end{array}$} \\
\hline Parameters & Thick flaked rice & Roasted flaked rice \\
\hline \multicolumn{3}{|c|}{ Dimensional properties } \\
\hline Length (mm) & $4.93 \pm 0.18$ & $4.10 \pm 0.33$ \\
\hline Breadth (mm) & $1.55 \pm 0.02$ & $2.33 \pm 0.08$ \\
\hline Thickness (mm) & $4.63 \pm 0.08$ & $4.99 \pm 0.15$ \\
\hline GMD (mm) & $67.42 \pm 2.22$ & $78.50 \pm 9.04$ \\
\hline $\mathrm{S}_{\mathrm{a}}\left(\mathrm{mm}^{2}\right)$ & $37.81 \pm 2.60$ & $31.36 \pm 1.55$ \\
\hline $\mathrm{R}_{\mathrm{a}}(\%)$ & $43.27 \pm 0.51$ & $38.25 \pm 1.37$ \\
\hline Sphericity (\%) & $13.06 \pm 0.59$ & $13.07 \pm 0.99$ \\
\hline \multicolumn{3}{|l|}{ Gravimetric properties } \\
\hline TKW (g) & $24.28 \pm 1.45$ & $22.97 \pm 0.60$ \\
\hline B.D. $\left(\mathrm{kg} / \mathrm{m}^{3}\right)$ & $353.80 \pm 43.82$ & $361.53 \pm 4.95$ \\
\hline T.D. $\left(\mathrm{kg} / \mathrm{m}^{3}\right)$ & $1108.95 \pm 23.35$ & $824.30 \pm 40.52$ \\
\hline POR $(\%)$ & $68.09 \pm 3.90$ & $56.06 \pm 2.50$ \\
\hline \multicolumn{3}{|l|}{ Frictional properties } \\
\hline AOR (degree) & $40.97 \pm 1.13$ & $52.70 \pm 0.74$ \\
\hline CFGI & $0.46 \pm 0.04$ & $0.37 \pm 0.09$ \\
\hline CFPPER & $0.43 \pm 0.02$ & $0.43 \pm 0.03$ \\
\hline CFPPAR & $0.42 \pm 0.02$ & $0.44 \pm 0.01$ \\
\hline $\mathrm{CFG}$ & $0.52 \pm 0.03$ & $0.41 \pm 0.04$ \\
\hline
\end{tabular}

Preparation of roasted flaked rice: Roasting machine with precise controlled temperature and timer controller has been developed to perform roasting experiment. About $40 \mathrm{~g}$ raw flaked rice was transferred into pre heated $120 \mathrm{~g}$ common salt in the roasting pan. The developed roasting machine was preset to the pre-specified temperature as per the designed combinations of temperature $\left(260-340{ }^{\circ} \mathrm{C}\right.$ ) and time (26 to 60 s) for roasting of flaked rice (Table-3). After roasting, samples were cooled to room temperature, weighed and transferred to air tight container for further analysis.

Chemical analysis: Moisture, fat, ash, protein and crude fiber content of flaked and roasted flaked rice were determined using standard procedure [31]. Total carbohydrate was calculated by the difference method [32]. The total starch, amylose content and resistant starch content were estimated using anthrone reagent method [33] and alkaline steeping method [31,34], respectively.

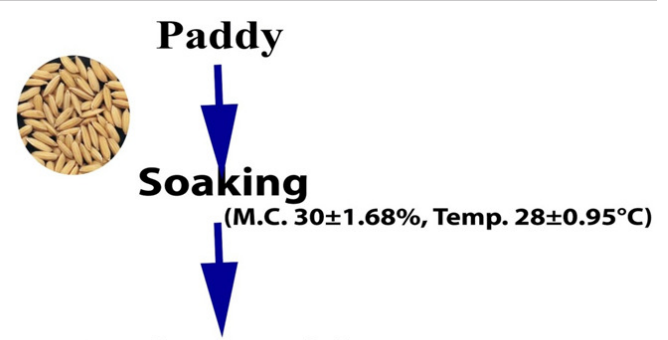

Soaked Paddy

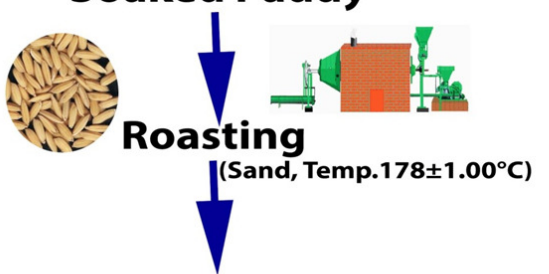

Roasted Paddy

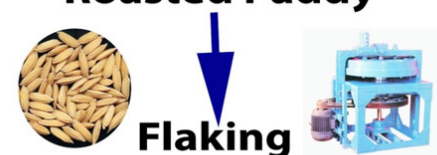

(M.C. $19 \pm 1.5 \%$, Temp. $\left.42 \pm 1.5^{\circ} 0 \mathrm{C}\right)$

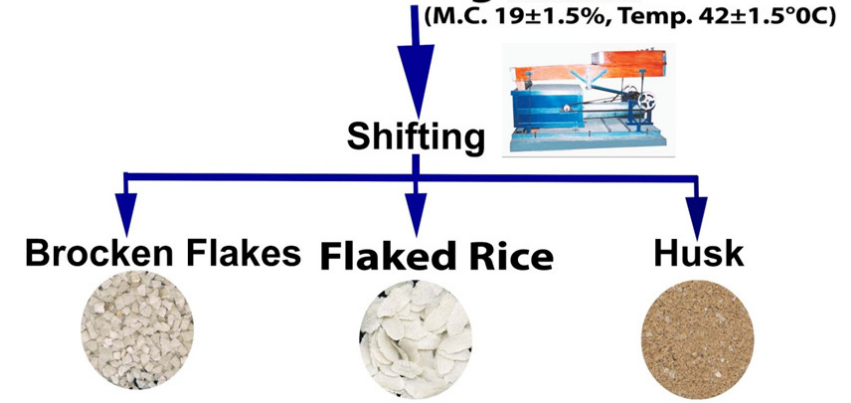

Fig. 3. Process flow diagram for the development of flaked rice

Hydroxymethyl furfural (HMF): About $5 \mathrm{~g}$ sample was dispersed in $25 \mathrm{~mL}$ distilled water and transferred to $50 \mathrm{~mL}$ volumetric flask. $0.5 \mathrm{~mL}$ each of Carrez solution I and II were added and make up volume to the mark with distilled water. The solution was filtered through ash-less filter paper No. 42; rejecting the first $10 \mathrm{~mL}$ of the filtrate. Further $5 \mathrm{~mL}$ of filtrate was poured in each test tube and to which $5 \mathrm{~mL}$ distilled water was poured in one test tube and $5 \mathrm{~mL}$ of sodium bisulphate

TABLE-3

CENTRAL COMPOSITE ROTATABLE DESIGN WITH EXPERIMENTAL VALUES OF RESPONSES VARIABLE

\begin{tabular}{|c|c|c|c|c|c|c|c|c|c|c|}
\hline \multirow{3}{*}{ S. No. } & \multicolumn{4}{|c|}{ Independent variables } & \multirow{2}{*}{\multicolumn{6}{|c|}{ Dependent variables }} \\
\hline & \multicolumn{2}{|c|}{ Coded form } & \multicolumn{2}{|c|}{ Un-coded form } & & & & & & \\
\hline & Temperature & Time & Temp. $\left({ }^{\circ} \mathrm{C}\right)$ & Time (s) & WI & YI & $\mathrm{HD}(\mathrm{N})$ & ER & HMF (mg/kg) & OAA \\
\hline 1 & -1 & -1 & 272 & 26 & 66.20 & 34.82 & 128.32 & 1.58 & 3.14 & 7.93 \\
\hline 2 & 1 & -1 & 328 & 26 & 67.30 & 34.54 & 87.06 & 2.57 & 6.35 & 7.37 \\
\hline 3 & -1 & 1 & 272 & 54 & 67.89 & 30.03 & 132.46 & 2.18 & 5.02 & 7.13 \\
\hline 4 & 1 & 1 & 328 & 54 & 68.02 & 35.19 & 78.34 & 2.96 & 6.20 & 7.67 \\
\hline 5 & -1.414 & 0 & 260 & 40 & 65.57 & 34.19 & 141.67 & 1.68 & 3.84 & 7.80 \\
\hline 6 & 1.414 & 0 & 340 & 40 & 66.90 & 37.68 & 67.06 & 3.13 & 6.82 & 8.33 \\
\hline 7 & 0 & -1.414 & 300 & 20 & 67.95 & 33.13 & 118.17 & 1.98 & 4.89 & 7.23 \\
\hline 8 & 0 & 1.414 & 300 & 60 & 68.76 & 28.41 & 96.04 & 2.70 & 5.14 & 7.17 \\
\hline 9 & 0 & 0 & 300 & 40 & 68.80 & 30.84 & 112.59 & 2.52 & 4.48 & 8.43 \\
\hline 10 & 0 & 0 & 300 & 40 & 68.71 & 31.04 & 117.22 & 2.51 & 4.33 & 8.53 \\
\hline 11 & 0 & 0 & 300 & 40 & 69.04 & 31.36 & 112.37 & 2.56 & 4.31 & 8.27 \\
\hline 12 & 0 & 0 & 300 & 40 & 68.97 & 30.28 & 112.03 & 2.46 & 4.41 & 8.61 \\
\hline 13 & 0 & 0 & 300 & 40 & 68.86 & 30.76 & 107.23 & 2.62 & 4.13 & 8.67 \\
\hline
\end{tabular}

$\mathrm{WI}=$ Whiteness index, $\mathrm{YI}=$ Yellowness Index, $\mathrm{HD}=$ Hardness, ER = Expansion ratio, HMF = Hydroxyl methyl furfural content, OAA = Sensory overall acceptability. 
solution in second test tube. Hydroxyl methylfurfural was determined at $284 \mathrm{~nm}$ against reference solution at $336 \mathrm{~nm}$. Hydroxymethyl furfural was calculated using the eqn. 1 [35].

$$
\operatorname{HMF}(\mathrm{mg} / \mathrm{kg}) \frac{\left(\mathrm{A}_{284}-\mathrm{A}_{336}\right) \times 149.7 \times 5 \times \mathrm{D}}{\mathrm{W}}
$$

where: $\mathrm{A}_{284}=$ absorbance at $284 \mathrm{~nm} ; \mathrm{A}_{336}=$ absorbance at 336 $\mathrm{nm} ; \mathrm{D}=$ dilution factor; $\mathrm{W}=$ weight in $\mathrm{g}$ of sample

Pasting characteristics: Pasting properties of the raw rice, flaked rice and salt roasted rice were evaluated using the Rapid Visco Analyzer (RVA, Newport Scientific, Australia). $25 \mathrm{~g}$ of distilled water was weighed into canister and $3.5 \mathrm{~g}$ of each sample was transferred separately into it $[22,23]$. The rotating paddle was placed into the canister and jogged to disperse the sample. The parameters recorded are shown in the form of different peaks. Heating and cooling cycle programs were set which were held at $70{ }^{\circ} \mathrm{C}$ for $1 \mathrm{~min}$, heated to $95{ }^{\circ} \mathrm{C}$ for $2 \mathrm{~min}$ and then held for another $2 \mathrm{~min}$ at $50{ }^{\circ} \mathrm{C}$. Parameters were assessed for peak viscosity (PV), trough viscosity (TV) (minimum viscosity at $95^{\circ} \mathrm{C}$ ), break down viscosity (BDV), final viscosity (FV), set back viscosity (SBV), peak time (PT) and pasting temperature (PT). The typical rapid visco analyzer curve is represented for the parameters. All experimental properties were measured in triplicate.

Fourier transform infrared spectroscopy (FTIR): $2 \mathrm{mg}$ of sample each of raw rice, roasted rice, flaked rice and salt roasted flaked rice flours were thoroughly mixed with desiccated potassium bromide $(50 \mathrm{mg})$ in a mortar and pestle. This mixture was used to prepare a thin pellet under palletizer machine and the infrared absorption spectra of the prepared pellets were obtained using FTIR, spectrometer (Shimadzu, Tokyo, Japan) set with potassium bromide and a deuterated triglycine sulfate (DTGS) detector. The spectra were recorded at a resolution of $2 \mathrm{~cm}^{-1}$ and in intensity range of $4000-500 \mathrm{~cm}^{-1}$.

Scanning electron microscopy (SEM): Morphological properties of raw rice, flaked rice and salt roasted flaked rice samples were scanned using scanning electron microscopy (SEM) (Jeol JSM-6510LV, Tokyo, Japan). Samples were mounted on different aluminum stubs using double-sided conductive tapes. All samples were coated with gold under vacuum and then scanned under different magnification to get a clear micrograph [23].

X-ray powder diffraction (XRD) measurements: For the analysis of X-ray diffraction the raw rice, roasted rice, flaked rice and salt roasted flaked rice were ground using dry grinding process. In the dry grinding process, the each rice samples were individually ground into flour using the mixer grinder (Sujata, Mixer) and passed through 100 mesh sieves. Moisture content of the rice flours varied in the range of 11.12$12.13 \%$ (dry weight basis). The powdered diffraction technique was pertain to obtain the $\mathrm{X}$-ray diffraction pattern using an X-ray diffractometer (Rigaku Denki Co. Ltd., Japan) with the following operating conditions: $40 \mathrm{kV}, 30 \mathrm{~mA}$ using $\mathrm{Cu}-\mathrm{K} \alpha \mathrm{X}$-rays of wavelength $(\lambda)=1.54056 \AA$ and data was in use for the $2 \theta$ range of $10-40^{\circ}$ with a resolution of $0.01^{\circ}$ for each step [22]. Relative crystallinity ( $\mathrm{RC}$ ) of raw rice, roasted rice, flaked rice and salt roasted rice flour was estimated using equation $\mathrm{RC}(\%)=\left[\mathrm{A}_{c} /\left(\mathrm{A}_{c}+\mathrm{A}_{\mathrm{a}}\right)\right] \times 100$, where $\mathrm{A}_{\mathrm{c}}$ is the crystalline area and $\mathrm{A}_{\mathrm{a}}$ is the amorphous area on the $\mathrm{X}$-ray diffractograms. A smooth curve which connected peak baselines was plotted on diffractograms. Crystalline area is the above the smooth and amorphous area is the lower area between smooth curve and the linear baseline.

Dimensional and gravimetric properties: Dimensional properties were calculated as per the prescribed method $[6,7,36]$. Dimensions of samples were measured using vernier caliper (Mitutoyo Corporation, Japan) to the accuracy of 0.001 $\mathrm{mm}$. Geometric mean dimension, surface area, aspect ratio and sphericity were thus determined adopting the prescribed methods [8,13,16,27,37-39].

Thousand kernel weight (TKW): Specified numbers of flaked rice kernels were counted manually and the weight of the sample were recorded using balance (Ishida Co. Ltd., Japan) to precision of $\pm 0.001 \mathrm{~g}$ to obtain thousand kernel weight.

Whiteness index (WI): The colour of roasted flaked rice was measured in the form of L, a and b values using Hunter Lab Chroma meter (Konica Minolta Sensing, Inc., Model No.CR-400, Japan). The terms indicate Hunter L* (lightness, ranging 0-100 indicating black to white) $\mathrm{a}^{*}$ [green (-) to red $(+)]$ and $\mathrm{b}^{*}$ [blue (-) to yellow (+)] [5,40]. The recorded values were used for calculating the whiteness index. Whiteness index represents extent of whiteness $[41,42]$ of the product. The whiteness index was calculated using eqn. 2 .

$$
\mathrm{WI}=\sqrt{\left(100-\mathrm{L}^{* 2}\right) \mathrm{a}^{* 2}+\mathrm{b}^{* 2}}
$$

Yellowness index (YI): Yellowness index value indicates the degree of yellow colour of product. The yellowness index value is the ratio of yellowness value $\left(b^{*}\right)$ and whiteness $\left(a^{*}\right)$ value. The yellowness index value was calculated using eqn. 3 .

$$
\text { Yellowness index }(\mathrm{YI})=\frac{142.86 \mathrm{~b}^{*}}{\mathrm{~L}^{*}}
$$

Hardness (HD): Hardness of the sample was determined by crushing method using a TA-XT2 Texture Analyzer (Stable Microsystems, Surrey, UK) equipped with a $50 \mathrm{~kg}$ load cell. A $5 \mathrm{~mm}$ diameter stainless steel probe P5. A single compression force versus time program was used to compress single roasted flaked rice kernel along the thickness, at a test speed of $2 \mathrm{~mm} / \mathrm{s}$, post speed $10 \mathrm{~mm} / \mathrm{s}, 80 \%$ strain and $5 \mathrm{~g}$ of trigger force. The maximum peak value indicating first crack of product at a one point was recorded and the obtained value was used as a measurement for hardness [43].

Expansion ratio (ER): Expansion ratio was calculated by using ratio of final volume after roasting and initial volume of raw flaked rice before roasting. The expansion ratio was calculated using eqn. 4 [44].

$$
\text { Expansion ratio }(E R)=\frac{V_{2}}{V_{1}}
$$

$\mathrm{V}_{1}=$ Initial volume before expansion; $\mathrm{V}_{2}=$ Final volume after expansion.

Sensory evaluation (OAA): Sensory evaluation of roasted flaked rice was carried out using 9 point hedonic rating scale [32] by a semi trained panel consisting of 15 members from the department of Food Engineering and Technology, SLIET, campus, Longowal, Punjab, India. The panel evaluated the roasted flaked rice for sensory parameters such as sensory colour, taste and overall acceptability. 
Experimental design and optimization: Response surface methodology (RSM) was adopted in the experimental design and analysis [45-54]. The experiments were conducted according to central composite rotatable design (CCRD) having two independent variables $(\mathrm{k}=2)$ i.e. temperature and time at five levels. The experimental combinations are presented both in coded and un-coded form of independent variables (Table-3). Total 13 experimental combinations were explored, which are 4 factorial experimental points, 4 axial points and 5 central point experiments. Total number of experimental combinations $=2^{\mathrm{k}}+2 \times \mathrm{k}+$ Central point experiment. Five different Levels for each experiment in coded form are, $-\alpha$, $-1,0,+1,+\alpha$. Where, $\alpha=(2)^{\mathrm{k} / 4}=(2)^{1 / 2}=1.414$.

The ranges of time and temperature were decided as per the preliminary conducted experiments and per the literature survey for the roasting of cereals. The lowest and highest levels for the temperature were 272 and $328^{\circ} \mathrm{C}$ and time $26 \mathrm{~s}$ and 54 $\mathrm{s}$. The flaked rice to salt ratio was kept constant $(1: 3(\mathrm{w} / \mathrm{w})$ for all the experiments. Multiple response (MR) optimization of the variables were carried out considering the response variables i.e. whiteness index, yellowness index, expansion ratio $(\mathrm{mL} / \mathrm{g})$, hardness $(\mathrm{N})$, hydroxyl methylfurfural $(\mathrm{mg} / \mathrm{kg})$ and overall acceptability using Stat-Ease software (Stat-Ease, version 6.01, Stat-Ease Inc., MN) $[51,55]$.

The second order polynomial eqn. 5 was fitted to the experimental data of each dependent variable as given below:

$$
\mathrm{Y}_{\mathrm{k}}=\beta_{\mathrm{k}_{0}}+\sum_{\mathrm{i}=1}^{2} \beta_{\mathrm{k}_{\mathrm{i}}} \mathrm{x}_{\mathrm{i}}+\sum_{\mathrm{i}=1}^{2} \beta_{\mathrm{k}_{\mathrm{ii}}} \mathrm{x}_{\mathrm{i}}^{2}+\sum_{\mathrm{i} \neq \mathrm{j}=1}^{2} \mathrm{~b}_{\mathrm{k}_{\mathrm{ij}}} \mathrm{x}_{\mathrm{i}} \mathrm{x}_{\mathrm{j}}+\mathrm{e}
$$

where $\mathrm{Y}_{\mathrm{k}}=$ response variable; $\mathrm{Y}_{1}=$ whiteness index, $\mathrm{Y}_{2}=$ yellowness index, $\mathrm{Y}_{3}=$ hardness, $\mathrm{Y}_{4}=$ expansion ratio, $\mathrm{Y}_{5}=$ hydroxymethyl furfural and $\mathrm{Y}_{6}=$ overall acceptance; $\mathrm{x}_{\mathrm{i}}$ represent the coded independent variables $\left(\mathrm{x}_{1}=\right.$ process temperature, $x_{2}=$ process duration); where $\beta_{\mathrm{k}_{0}}$ was the value of the fitted response at the centre point of the design, i.e., point $(0,0), \mathrm{B}_{\mathrm{k}_{\mathrm{i}}}, \mathrm{B}_{\mathrm{k}_{\mathrm{ii}}}$ and $\mathrm{B}_{\mathrm{k}_{\mathrm{ij}}}$ were the linear, quadratic and crossproduct regression coefficients, respectively and the $\mathrm{e}$ is relative error.

Statistical analysis: One-way analysis of variance (ANOVA) was used to assess data by using SPSS 16.0 software. Values are expressed as means \pm standard deviation and differences were considered significant at level of $\mathrm{p} \leq 0.05$ [13].

Process temperature measurement: The temperature of product at during processing steps was measured using infrared thermometer MEXTECH DT-8811 (-50 to about $\left.550{ }^{\circ} \mathrm{C}\right)$.

\section{RESULTS AND DISCUSSION}

Development of flaked rice: The selected promising Gurjari variety of rice belongs to the indica sub-species of Oryza sativa. The rice starch is composed of amylase, amylopectin and the resistant starch. Amylose content is used for the classification of rice into glutinous or waxy rice (0.8$1.3 \%)$ and aglutinous or non-waxy rice (8-37\%) [22]. The non-waxy low amylose rice (9-20\%) is preferred for crackers and biscuits, medium amylose rice (20-25\%) is suitable for flaked rice, puffed rice, popped rice and extruded pasta whereas high amylose rice $(>25 \%)$ is favoured for the preparation of parboiled rice. The used rice was found to be of medium amylose content $(20.48 \pm 1.27 \%)$.

Our work on changes in the quality characteristics on the development of flaked rice may be seen elsewhere [23]. Dimensional characteristic, the length to breadth ratio (L/B ratio) is used to classify the rice into fine or slender $(\geq 3)$, medium (2-3) and coarse $(\leq 2)$. The $\mathrm{L} / \mathrm{B}$ ratio was found to be $2.86 \pm 0.04$ for the Gurjari rice. The fine variety of rice is milling susceptible and yield less head rice with lots of broken on milling or polishing $[13,15]$. Flaking of raw rice cannot be done due to low moisture content $(10.32 \pm 0.28 \%)$ of dry kernels and thus liable for breakage. The milled rice on cooking becomes soft and mashy. Parboiling is the process of cooking the rice in form of paddy, makes the rice too soft and thus difficult to handle. Paddy is thus soaked in water to increase the moisture content to $30 \%$ and dry sand roasting (178-180 ${ }^{\circ} \mathrm{C}$ ) is applied until one or two paddy grains start puffing (28$30 \mathrm{~s}$ ) mainly to make semi-plastic rice before it is subjected for flaking in the edge-runner (Fig. 3). The bran and husk layer on roasting become brittle and get pulverized and separates during the process of flaking. The endosperm gets flattened and yield $68.88 \pm 0.87 \%$ thick flakes having $5.15 \pm$ $0.29 \%$ broken on 2 min rotation in edge-runner.

Development and process optimization for roasted flaked rice: Flaked rice is often roasted or fried before it is used for the preparation of popular traditional snacks. Roasting is a time consuming and requires process expertise to get high quality product. The expansions of grains take place and make the product fragile if not properly handled. The particle distribution for projected area in the process of roasted flaked rice has been shown (Fig. 4). Central composite rotatable design (CCRD) of Response surface methodology (RSM) was adapted to optimize time (26 to $54 \mathrm{~s}$ ) and temperature $\left(272\right.$ to $328^{\circ} \mathrm{C}$ ) combination for roasting and to study the effect on various quality characteristics of obtained roasted flaked rice (Fig. 5). The responses viz., whiteness index (WI), yellowness index (YI), hardness (HD), expansion ratio (ER), hydroxymethyl furfural (HMF) and overall acceptability (OAA) data as obtained from the experimental run (Table-3) were used to
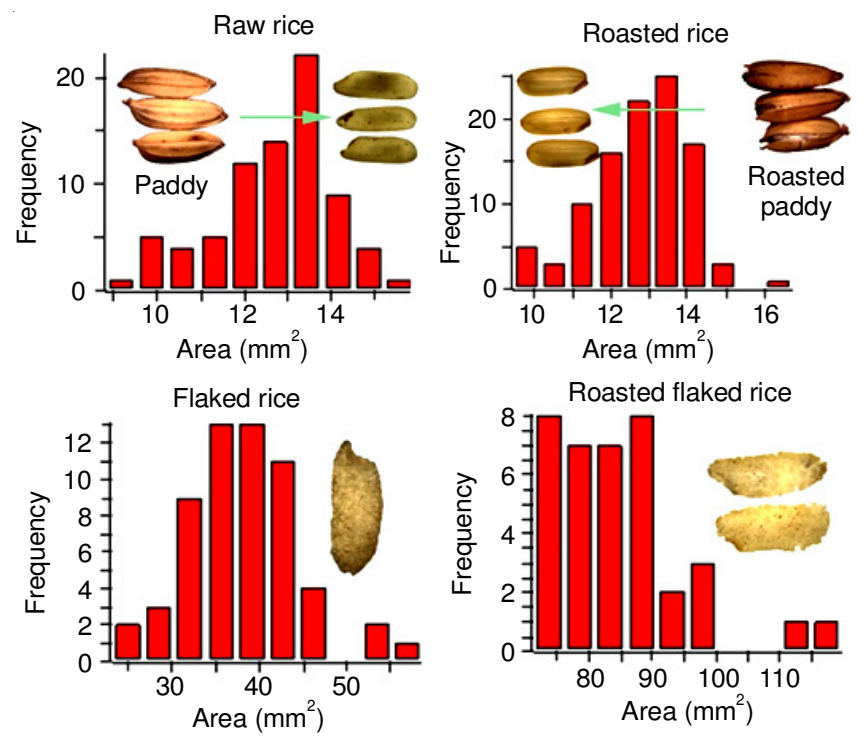

Fig. 4. Projected area of roasted flaked rice on different levels of processing 


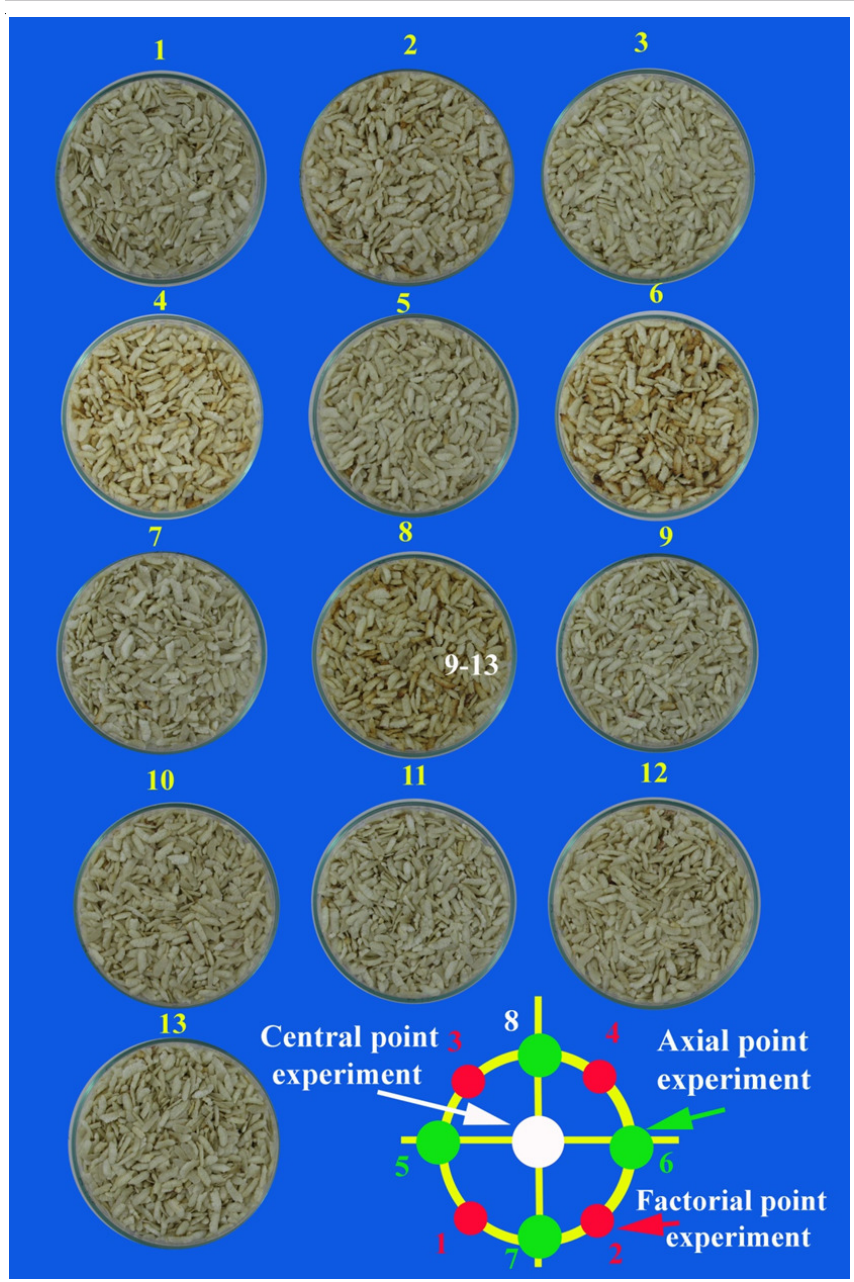

Fig. 5. Roasted flaked rice as dependent on time temperature combinations

develop the quadratic models and adequacy of model fitting was adjudged on selected parameters (Table-4).

Whiteness index (WI) and yellowness index (YI): Degree of whiteness index explains the extent of whiteness of product and is directly related to the acceptability of roasted flaked rice. Colour parameters L, a \& b values for the obtained roasted flaked rice (Fig. 6) were measured to study the effect of time and temperature on whiteness index of roasted flakes. The whiteness index of roasted flaked rice varied from 66.20 to 69.04 (Table-3). The maximum whiteness index of roasted flaked rice was found at the combination of time and temperature at the level of assumed optimum condition while minimum value of whiteness index was found when flakes were roasted at $272{ }^{\circ} \mathrm{C}$ for $26 \mathrm{~s}$. The fitted model (eqn. 6) parameters, the coefficients and constant with determined statistical findings are cited in Table-4.

$$
\begin{aligned}
\text { Whiteness index }= & 68.88+0.39 \mathrm{X}_{1}+0.44 \mathrm{X}_{2}- \\
& 1.31 \mathrm{X}_{1}^{2}-0.25 \mathrm{X}_{2}^{2}-0.24 \mathrm{X}_{1} \mathrm{X}_{2}
\end{aligned}
$$

where, $X_{1}$ and $X_{2}$ are coded values of temperature and time.

According to the regression results (Table-4), both temperature and time showed a significant $(\mathrm{p} \leq 0.01)$ linear positive effect on whiteness index. Increase in whiteness index increased the whitish appearance of roasted flaked rice. Combined effect of time and temperature on whiteness index showed a negative effect as evident from the darkening of product beyond the optimal combination of time and temperature (Fig. 6).

Degree of yellowness index explains the extent of colour of product towards yellow. The yellowness index of roasted flaked rice varied in the range of 28.41 to 37.68 (Table-3). The maximum yellowness index of roasted flaked rice was found at the highest roasting temperature exposure (Table-3). A minimum value of yellowness index of roasted flaked rice was found when time of roasting given was found maximum. The constant and coefficient of independent variable obtained through applying multiple regressions on yellowness index data could be represented through eqn. 7 :

$$
\begin{aligned}
\text { Yellowness index }= & 30.86+1.23 \mathrm{X}_{1}-1.35 \mathrm{X}_{2}+ \\
& 2.61 \mathrm{X}_{1}^{2}+1.36 \mathrm{X}_{1} \mathrm{X}_{2}
\end{aligned}
$$

Temperature was found to be having a positive significant $(p \leq 0.01)$ effect on the yellowness index. The results confirm the facts of increase in yellow colour with respect to increase in temperature and time combination (Table-3). Dry roasting

\begin{tabular}{|c|c|c|c|c|c|c|}
\hline Parameters & WI & YI & $\mathrm{HD}(\mathrm{N})$ & ER & HMF (mg/Kg) & OAA \\
\hline$\beta_{\mathrm{o}}$ & 68.88 & 30.86 & 112.29 & 2.53 & 4.33 & 8.50 \\
\hline Temperature $\left(\mathrm{X}_{1}\right)$ & $0.39^{* * *}$ & $1.23^{* * *}$ & $-25.11^{* * *}$ & $0.48^{* * *}$ & $1.08^{* * *}$ & $0.09^{* * *}$ \\
\hline Time $\left(\mathrm{X}_{2}\right)$ & $0.44^{* * *}$ & $-1.35^{* * *}$ & $-4.48^{\mathrm{ns}}$ & $0.25^{* * *}$ & $0.26^{* * *}$ & $-0.07^{\mathrm{ns}}$ \\
\hline $\mathrm{X}_{1}^{2}$ & $-1.31^{* * *}$ & $2.61^{* * *}$ & $-3.76^{* * *}$ & $-0.08^{\mathrm{ns}}$ & $0.50^{* * *}$ & $-0.24^{\mathrm{ns}}$ \\
\hline $\mathrm{X}_{2}{ }^{2}$ & $-0.25^{* *}$ & $0.03^{\mathrm{ns}}$ & $-2.39^{* * *}$ & $-0.11^{* * *}$ & $0.34^{* * *}$ & $-0.68^{* * *}$ \\
\hline $\mathrm{X}_{1} \cdot \mathrm{X}_{2}$ & $-0.24^{*}$ & $1.36^{* * *}$ & $-3.21^{* * *}$ & $-0.05^{\mathrm{ns}}$ & $-0.50^{\mathrm{ns}}$ & $0.28^{* * *}$ \\
\hline Lack of fit (F-value) & 0.0728 & 0.250 & 0.180 & 0.351 & 0.086 & 0.319 \\
\hline Pure error & 0.067 & 0.63 & 7.91 & 0.014 & 0.069 & 0.10 \\
\hline Residual & 0.33 & 1.61 & 46.70 & 2.48 & 0.31 & 0.22 \\
\hline Total & 15.23 & 83.81 & 10282.17 & 0.029 & 13.42 & 4.01 \\
\hline $\mathrm{R}^{2}$ & 0.978 & 0.980 & 0.995 & 0.988 & 0.976 & 0.944 \\
\hline Adjusted $\mathrm{R}^{2}$ & 0.963 & 0.967 & 0.992 & 0.980 & 0.960 & 0.905 \\
\hline Adequate precision & 22.41 & 27.07 & 22.33 & 34.25 & 24.63 & 12.08 \\
\hline Chi square & 0.004 & 0.051 & 0.645 & 0.010 & 0.065 & 0.027 \\
\hline$\% \mathrm{E}$ & 0.005 & 0.014 & 0.055 & 0.027 & 0.168 & 0.024 \\
\hline
\end{tabular}
process at higher temperature results in browning of flakes at

TABLE-4

REGRESSION COEFFICIENTS OF FITTED MODELS STATISTICAL PARAMETERS FOR ADEQUECY OF MODEL FITTING

Level of significance $* * * \mathrm{p}<0.01 \%, * * \mathrm{p}<0.05 \%, * \mathrm{p}<0.1 \%$, ns: non-significant; $\mathrm{WI}=$ Whiteness index, YI $=$ Yellowness Index, HD $=$ Hardness, ER = Expansion ratio, $\mathrm{HMF}=$ Hydroxyl methyl furfural content, OAA = Sensory overall acceptability 


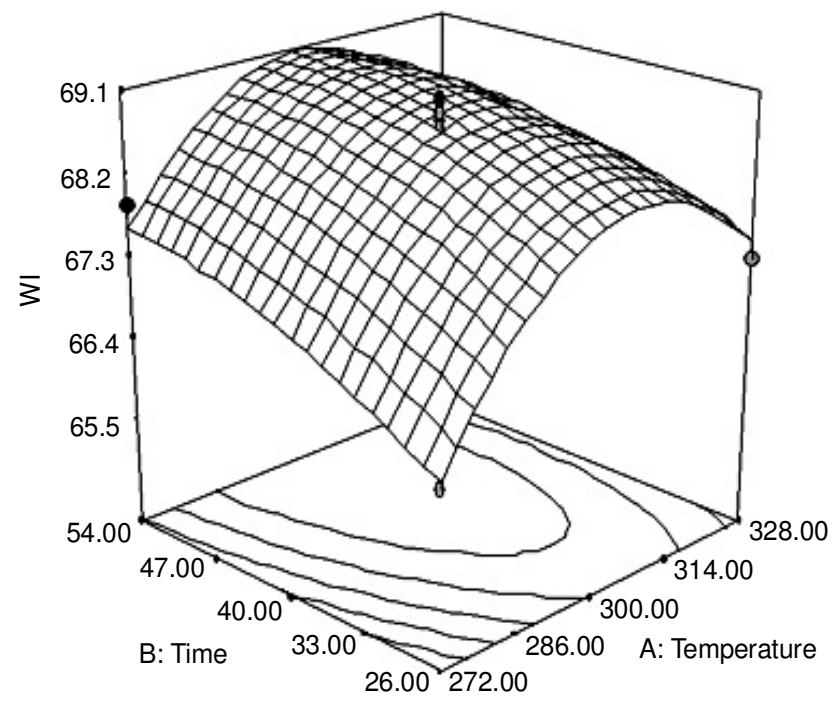

Whiteness index

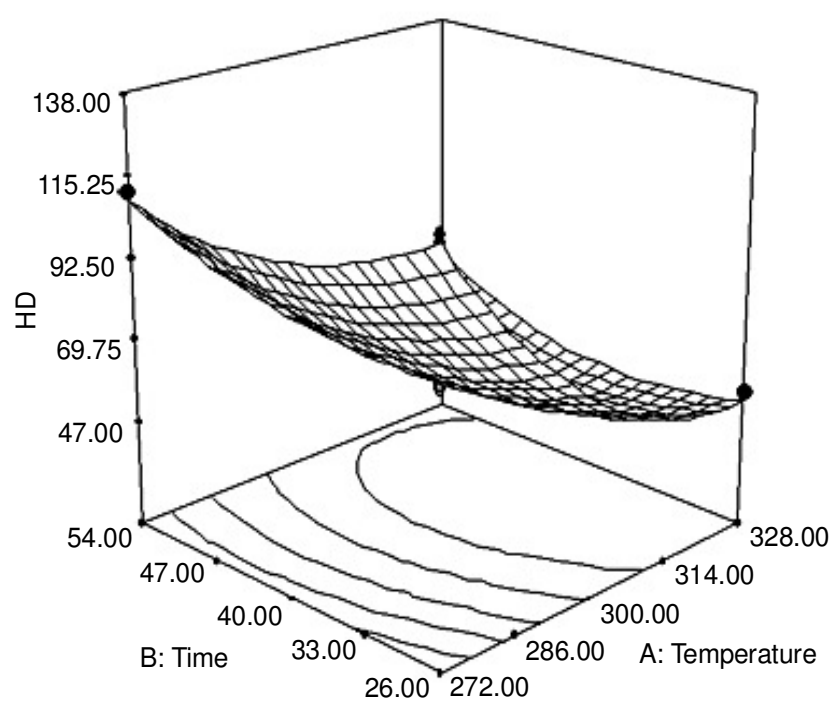

Hardness

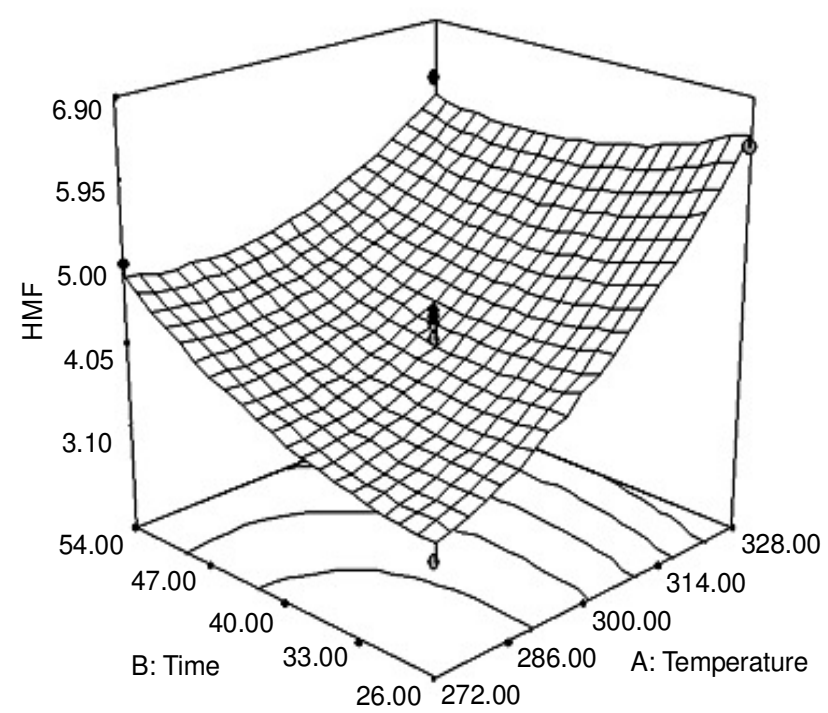

Hydroxyl methyl furfural

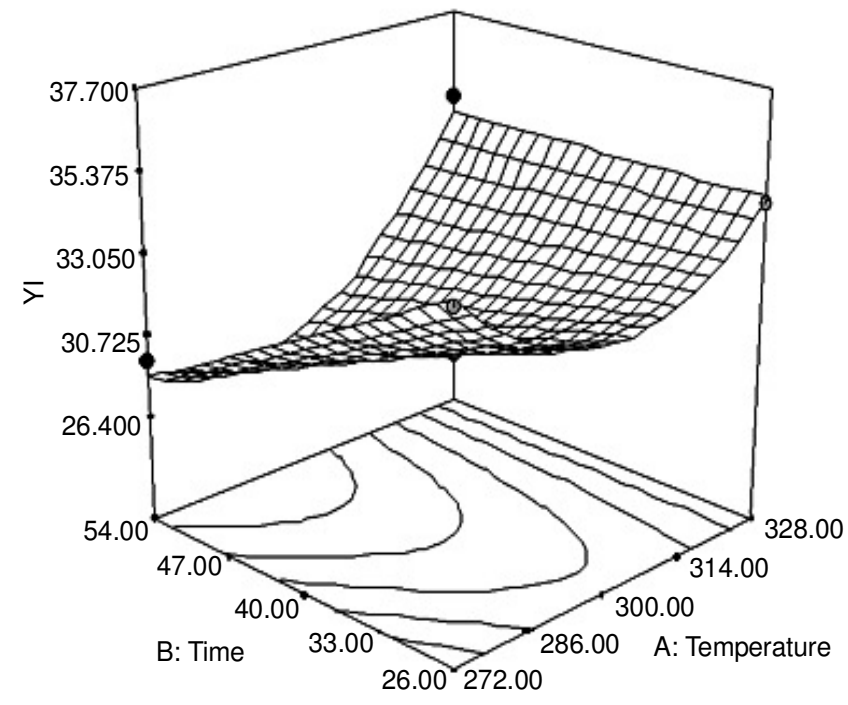

Yellowness index

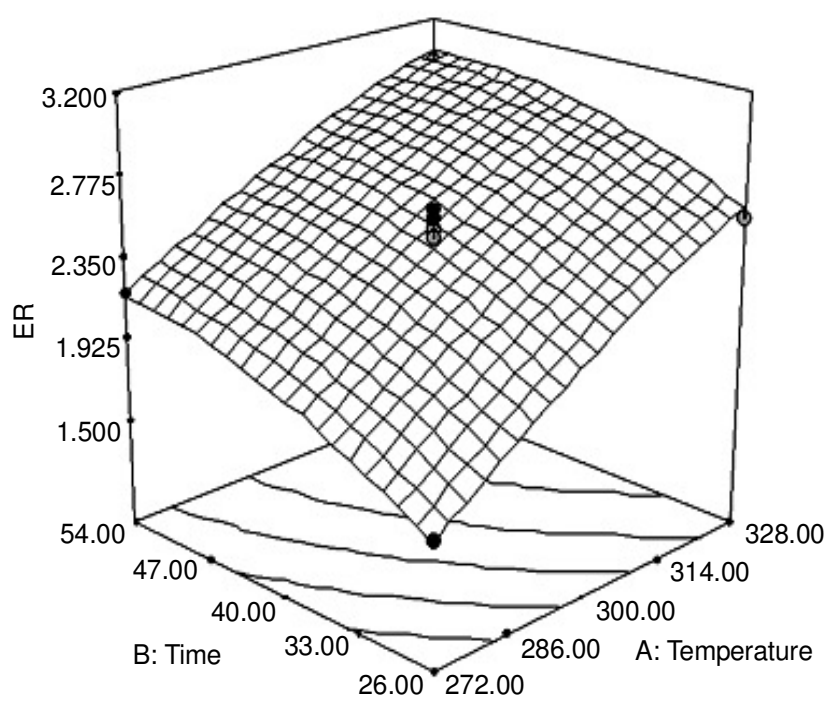

Expansion ratio

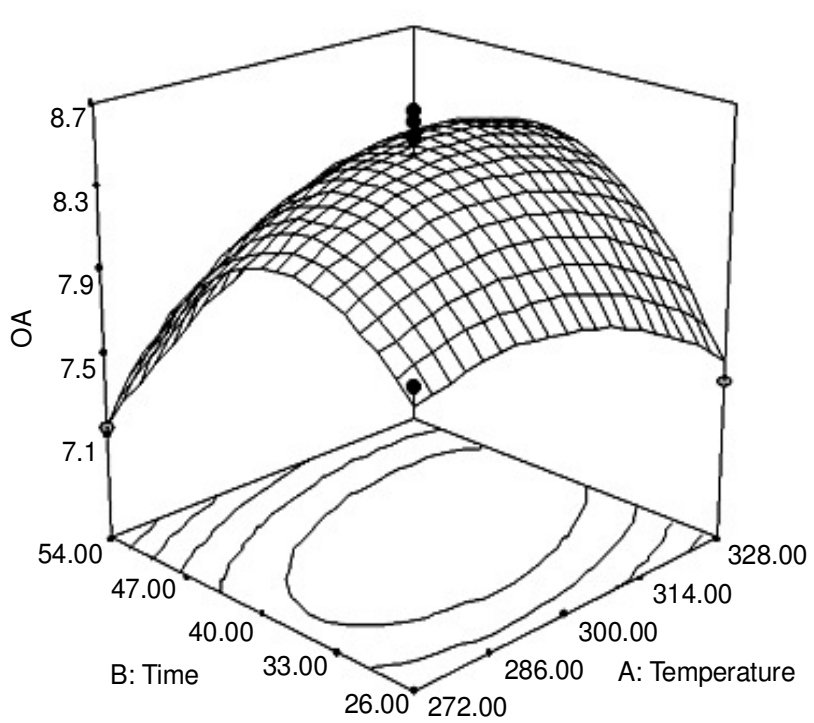

Overall acceptability

Fig. 6. Response surface plots for selected dependent variables 
the surface. The effect of time and temperature on the yellowness index is represented in form of response surface plot (Fig. 6). The higher $\mathrm{R}^{2}$ value with lower chi square, \% Error and RMSE for the whiteness index and yellowness index reflects the adequacy of the developed model in predicting the response (Table-4).

Hardness (HD): Hardness is the maximum force applied for compressing or deforming a product in the deformation curves [21]. Hardness value of roasted flaked rice varied from 67.06 to $141.67 \mathrm{~N}$ (Table-3). The magnitude and sign of regression coefficient of temperature showed the significant ( $p \leq 0.01$ ) negative effect on hardness of roasted flaked rice (Table-4). Minimum hardness of roasted flaked rice was found when temperature of roasting was highest and maximum on lowest temperature exposure. Model parameters, coefficients, constant with statistical findings are presented (Table-4). The value of hardness as dependent on temperature and time is presented through eqn. 8 :

$$
\begin{aligned}
\text { Hardness }= & 112.29-25.11 \mathrm{X}_{1}-3.76 \mathrm{X}_{1}^{2}- \\
& 2.39 \mathrm{X}_{2}^{2}-3.21 \mathrm{X}_{1} \mathrm{X}_{2}
\end{aligned}
$$

Increase in time or temperature of roasting result in the decreased hardness value of roasted flaked rice (Fig. 6). The developed model was found adequate as per the determined statistical parameters to adjudge the adequacy of the model (Table-4). Expansion of flaked rice during dry roasting dependent of the moisture present inside amylase-protein matrix try to release and develop pressure in form of water vapour at provided sudden increase in temperature during roasting, results in the puffing of starch granules. The similar results were reported for the puffing process at elevated temperature exposure to parboiled rice [25].

Expansion ratio (ER): Expansion ratio of roasted flaked rice was expressed as the degree of expansion from the original product subjected for roasting. Expansion ratio of roasted flaked rice varied from 1.58 to 3.13 (Table-3). The regression coefficient of temperature showed a significant $(\mathrm{p} \leq 0.01)$ positive effect on expansion ratio (Table-4). Maximum expansion ratio of roasted flaked rice was found at the highest exposed temperature. The minimum value of expansion ratio of roasted flaked rice was found to be at a combination of minimum temperature and time combination in the CCRD based conducted experiments. Least square method was adopted to fit the expansion ratio data in order to get full second order model having temperature and time as independent variables. Further, step wise regression was also applied to find out the significant parameters affecting the process and presented through eqn. 9:

Expansion ratio $=2.53+0.48 \mathrm{X}_{1}+0.25 \mathrm{X}_{2}-0.11 \mathrm{X}_{2}^{2}(9)$

Temperature and time have significantly affected the expansion ratio $(\mathrm{p} \leq 0.01)$ at linear level (Table-4). The surface plot showed a increasing peak in expansion ratio till it has achieved almost the assumed point value with increase in time mainly due to the negative sign of quadratic coefficient of time (Fig. 6). This increase in expansion ratio because of during roasting of flaked rice thus is more relied on time in process optimization. The coefficients of the model and other statistics are given in Table-4. The higher model F-value indicated that the developed model is significant. $\mathrm{R}^{2}$ of 0.988 further reflects reasonable agreement. Whereas, the value of adequate precision as 34.24 indicating a good fit of experimental data and the acceptability of the developed model for the prediction of expansion ratio in a roasting process of flaked rice.

Hydroxy methyl furfural (HMF): The hydroxyl methyl furfural is a heterocyclic compound, 5-(hydroxymethyl)-2furaldehyde that is formed during the thermal treatment of food. It involves reactions of amino acids, peptides or proteins with reducing sugars. This process is known as non-enzymatic browning. The reactive intermediates chain formed is called hydroxy methyl furfural [26]. Hydroxyl methyl furfural content of roasted flaked rice varied from 3.14-6.82 mg/kg (Table-3). Both temperature and time showed linear significant effect ( $p$ $\leq 0.01$ ) on hydroxyl methyl furfural content of roasted flaked rice (Fig. 6). Hydroxyl methyl furfural of roasted flaked rice was found highest at highest exposed temperature and minimum at factorial experimental points having minimum temperature and time combination. The model parameters, the coefficients and constant with determined statistical findings are presented (Table-4). The significant terms with the coefficient and constant as obtained through analysis of variance are depicted through eqn. 10:

$$
\begin{aligned}
\text { Hydroxy methyl furfural }= & 4.33+1.08 \mathrm{X}_{1}+0.26 \mathrm{X}_{2}+ \\
& 0.50 \mathrm{X}_{1}^{2}+0.34 \mathrm{X}_{2}^{2}
\end{aligned}
$$

Combination of time and temperature during roasting process shows in Table-4, a non-significant negative effect at interaction level. As the time and temperature increases of roasting process the non-enzymatic browning increases that results in formation of higher values of hydroxyl methyl furfural justify the linear significant effects of variables. Response surface plot shows that the hydroxyl methylfurfural content is influenced by the independent variables during the roasting process (Fig. 6).

The model F-value of 13.42 for hydroxyl methyl furfural content (Table-4) represents the model is statistically significant at $\mathrm{P} \leq 0.01$ with the coefficient of multiple determination $\left(\mathrm{R}^{2}\right)$ as 0.976 having the reasonable agreement towards applicability of model for is purpose $[45,51,56]$. The value of adequate precision as 24.63 further confirms that the developed model can be explored to predict the possible intermediaries. It could be observed from the eqn. 10 that the increase in either roasting temperature $\left(\mathrm{X}_{1}\right)$ or time $\left(\mathrm{X}_{2}\right)$ increases the hydroxyl methylfurfural content being the coefficient of $X_{1}$ and $X_{2}$ are positive (Fig. 6).

Overall acceptability (OAA): Sensory analysis is based on evaluation of product through the use of different senses simultaneously. Overall acceptability values of roasted flaked rice ranged from 7.13 to 8.67 (Table-3). Highest overall acceptability was found at the temperature $\left(300{ }^{\circ} \mathrm{C}\right)$ and time (40s) combination at the assumed optimum point. Regression analysis also showed temperature had significant positive $(\mathrm{p} \leq 0.01)$ effect on overall acceptability of roasted flaked rice (Table-4) and time had negative non-significant effect. From response surface plot (Fig. 6) it may be observed that the combination of temperature and time had significant $(\mathrm{p}<0.01)$ effect on overall acceptability of roasted flaked rice. The developed model with statistical findings is presented (Table-4). The 
significant terms as obtained for the quadratic are presented in eqn. 11:

$$
\text { Overall acceptability }=8.50+0.09 \mathrm{X}_{1}-0.68 \mathrm{X}_{2}^{2}+
$$

$$
0.28 \mathrm{X}_{1} \mathrm{X}_{2}
$$

The analysis of variance (ANOVA) for full second order polynomial models (eqn. 11) for sensory overall acceptability scores are given in Table-3. F-ratio for overall acceptability (38.22) scores was found more than table F value $(\mathrm{P} \leq 0.05)$. $\%$ E for sensory overall acceptability was 0.024 , whereas coefficient of multiple determinations $\left(\mathrm{R}^{2}\right)$ was 0.944 (Table-4). These values show that the models explained $>85 \%$ variability. A value of $\mathrm{R}^{2}$ of more than $80 \%$ is good for explaining the variability in the model $[57,58]$, while a minimum value of $85 \%$ for $\mathrm{R}^{2}$ as very good for explaining variance for sensory data [59]. The values of chi square and RMSE for the developed sensory overall acceptability model (eqn. 11) were found lower as 0.027 and 0.130 , respectively. Thus, the models developed for predicting sensory overall acceptability scores for roasted flaked rice dependent on roasting temperature and time were found adequate.

Optimization: The independent variables roasting temperature and time were optimized numerically using statistical software Design-expert 7.0. 0-version (Stat-Ease Inc., Minneapolis, USA). The independent variables were kept in range while the responses were maximized, minimized and in range based on the desirable characteristics of the roasted flaked rice. The following limits were proposed, the expansion ratio and overall acceptability were maximized; hydroxy methyl furfural content in final product was minimized and whiteness index, yellowness index and hardness were kept in range. The optimization process was applied for the roasting temperature 272 to $328{ }^{\circ} \mathrm{C}$ and roasting time 26 to $54 \mathrm{~s}$. The generated optimum level of independent variables as temperature $302{ }^{\circ} \mathrm{C}$ and time $41 \mathrm{~s}$ as the most desirable solution to get the optimum roasted flaked rice. From the graphical response analysis, it was found that optimum value temperature and time in similar combination.

\section{Characterization of optimized roasted flaked rice}

Physical properties: Changes in physical properties of such as dimensional, gravimetric and frictional characteristics were studied and compared with flaked rice (Table-2). The dimensional parameters of flaked rice were changed on roasting $13.06 \pm 0.59$ to $13.07 \pm 0.99 \mathrm{~mm}, 4.93 \pm 0.18$ to 4.10 $\pm 0.33 \mathrm{~mm}$ and $1.55 \pm 0.02$ to $2.33 \pm 0.08 \mathrm{~mm}$ for length, breadth and thickness, respectively. The geometric mean diameter was found to be increased significantly $(\mathrm{p} \leq 0.05)$ on roasting of flaked rice from $67.42 \pm 2.22$ to $78.50 \pm 9.04 \mathrm{~mm}$. Thousand kernel weight of roasted flaked rice was found to be decreased on roasting from $24.28 \pm 1.45$ to $22.97 \pm 0.60 \mathrm{~g}$, which may be due to loss of moisture and breakage of endosperm on the flattened sides. Bulk density was found to be increase from $353.80 \pm 43.82$ to $361.53 \pm 4.95 \mathrm{~kg} / \mathrm{m}^{3}$ whereas the true density was found to be reduced on roasting of flaked rice from $1108.95 \pm 23.35$ to $824.30 \pm 40.52 \mathrm{~kg} / \mathrm{m}^{3}$. The change in the dimensional attributes are the outcome of roasting at high temperature in the salt as heating medium which has expanded the compact structure of flaked rice (Fig. 4). The coefficients of static frictions on different surfaces have not found to be significantly affected. The angle of repose has found to be increased significantly mainly due to increased grain to grain friction and bulk density of roasted flaked rice (Table-2).

Chemical composition: The result of chemical composition of flaked rice and roasted flaked rice are shown in Table-1. Moisture content of roasted flaked rice was found to be reduced to $4.58 \pm 0.04 \%$ from $10.22 \pm 0.39 \%$ due to high temperature $\left(302{ }^{\circ} \mathrm{C}\right)$ exposure in hot salt medium for $41 \mathrm{~s}$. Fat, protein total ash and crude fiber varied insignificantly whereas carbohydrate content of roasted flaked rice is significantly ( $\mathrm{p} \leq 0.05$ ) affected mainly due to conversion into resistant starch. Resistant starch (RS) is the portion of starch that can resist digestion by pancreatic amylase of small intestine in 120 min of ingested food by human but fermented in colon. Resistant starch is the difference in total starch and the sum total of readily digestible starch (enzymatic conversion to glucose in $20 \mathrm{~min}$ ) and slow digestible starch (gets hydrolyzed to glucose after $100 \mathrm{~min}$ ). The conversion of starch into type III resistant starch during the process of flaking have various health benefits such as modify lipid metabolism, reduce the risk of colon cancer by the developed improved prebiotic properties.

Pasting properties: Determination of pasting behaviour using Rapid Visco Analyzer (RVA) is an important way to characterize the properties of starch rich food materials. The pasting behaviour and the typical pasting curves as obtained from Rapid Visco Analyzer are shown in Fig. 7. The pasting characteristics of Gurjari rice on processing leading to roasted flaked rice were assessed using Rapid Visco Analyzer. Effects of soaking, parboiling, compression and dry salt roasting on the pasting behaviour were compared (Fig. 8). The pasting point viscosity was found different in case of level of processing, showing the effect of processing (Table-5). The peak viscosity was found highest with the raw rice $(4149 \mathrm{cP})$, intermediate for the flaked rice $(1869 \mathrm{cP})$ and lowest for the roasted flaked rice $(902 \mathrm{cP})$. The similar trend has been observed for the hot paste, cool paste and set back viscosities of different stages of flaked rice. The final viscosity for raw rice, flaked rice and roasted flaked rice were 6921, 2684 and $1546 \mathrm{cP}$, respectively. Increase in final viscosity of raw rice during cooling may be attributed to increase the water holding capacity on amalgamation of amylopectin molecules. Thus, is reflected from the result that the dry heat roasting of moist paddy and mechanical compression on flaking process of rice mainly leads to initial partial gelatinization of starch granule and simultaneous leaching of amylose, which is further partially changed to resistant starch on dry heat roasting of flaked rice. The findings of break down viscosity of roasted flaked rice $(92 \mathrm{cP})$ was minimum followed by flaked rice $(245 \mathrm{cP})$ and raw rice $(1402 \mathrm{cP})$ as compared to setback viscosity again lowest for roasted flaked rice $(736 \mathrm{cP})$ followed by flaked rice $(1060 \mathrm{cP})$ and raw rice $(4174 \mathrm{cP})$, which further confirms the effect of processing.

Hardness: Hardness is important textural attributes used along with other mechanical parameters such as firmness, resistance, toughness, stiffness and rigidity. The compression force 


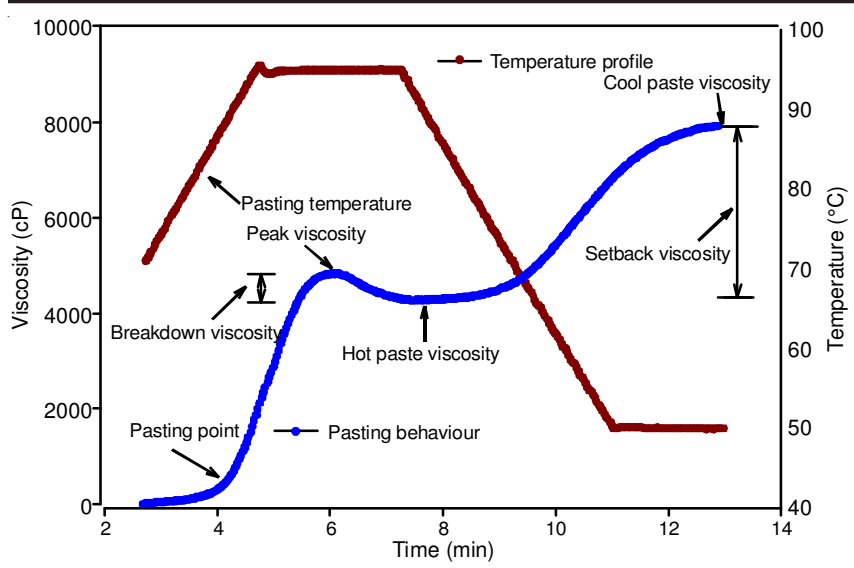

Fig. 7. Typical Rapid Visco Analyser (RVA) curve

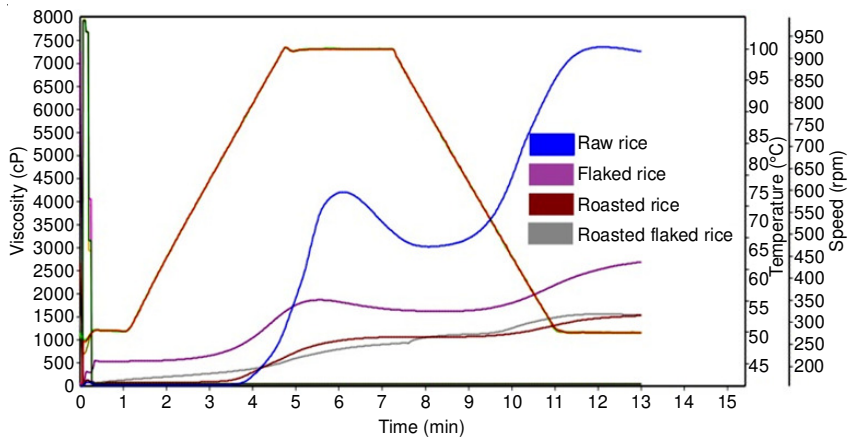

Fig. 8. Pasting properties of raw rice, roasted rice, flaked rice and salt roasted flaked rice

TABLE-5

PASTING PROPERTIES ON TRANSFORMATION TO ROASTED FLAKED RICE

\begin{tabular}{lcccc}
\hline & $\begin{array}{c}\text { Raw } \\
\text { rice }\end{array}$ & $\begin{array}{c}\text { Roasted } \\
\text { rice }\end{array}$ & $\begin{array}{c}\text { Flaked } \\
\text { rice }\end{array}$ & $\begin{array}{c}\text { Salt } \\
\text { roasted } \\
\text { flaked rice }\end{array}$ \\
\hline Peak viscosity $(\mathrm{cP})$ & 4149 & 1058 & 1869 & 902 \\
Trough viscosity $(\mathrm{cP})$ & 2747 & 993 & 1624 & 810 \\
Breakdown viscosity $(\mathrm{cP})$ & 1402 & 65 & 245 & 92 \\
Final viscosity $(\mathrm{cP})$ & 6921 & 1525 & 2684 & 1546 \\
Setback viscosity $(\mathrm{cP})$ & 4174 & 532 & 1060 & 736 \\
Peak time (min) & 6.07 & 7 & 5.53 & 7 \\
Pasting temperature $\left({ }^{\circ} \mathrm{C}\right)$ & 82.35 & 81.5 & 75.1 & 92 \\
\hline
\end{tabular}

(N) for the breakdown of samples varied significantly on level of processing leading to obtain the roasted flaked rice (Fig. 9). The degree of hardness was observed to decrease on processing of raw rice $(197.03 \mathrm{~N})$ to flaked rice $(176.60 \mathrm{~N})$ and further to roasted flaked rice $(107.23 \mathrm{~N})$. The change in hardness of grains may be attributed to the effect of dry heat roasting and further the mechanical compression to flattened form having lots of surface cracks or the damaged matrix appears on surface of the flaked rice. On the other hand, roasting further gelatinized the partially gelatinized starch and converted to the expanded form of the roasted flaked rice leads to the substantial reduction in the hardness of roasted flaked rice.

Fourier transform infrared spectroscopy (FTIR): FTIR spectra of raw rice, roasted rice, flaked rice and roasted flaked rice are shown in Fig. 10. Stretching bands at wave number $1018 \mathrm{~cm}^{-1}$ and $1658 \mathrm{~cm}^{-1}$ corresponds to the presence of functional group $-\mathrm{C}-\mathrm{O}$ and $-\mathrm{C}=\mathrm{O}$. The infrared spectra

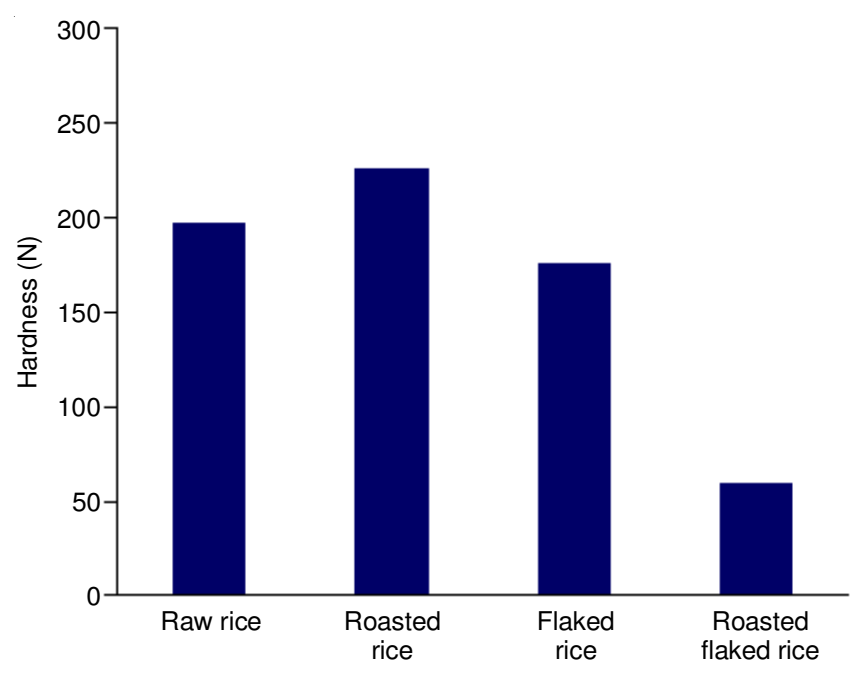

Fig. 9. Hardness (N) of roasted flaked rice on different levels of processing

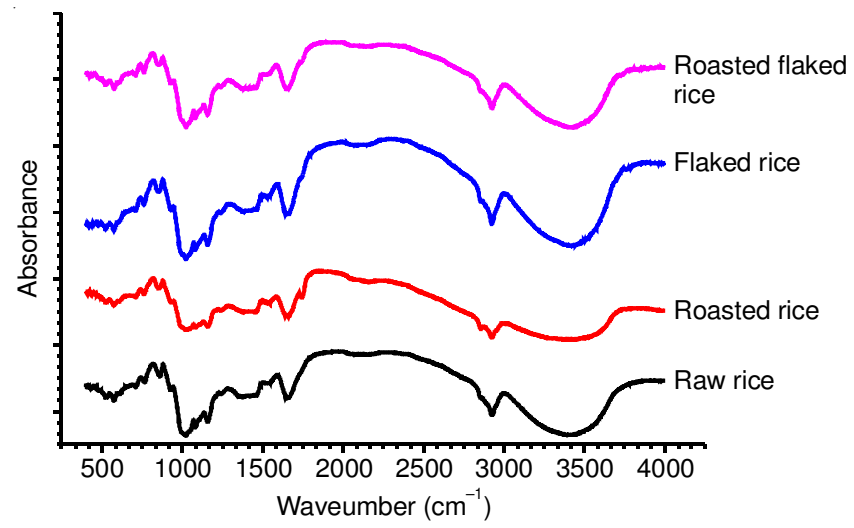

Fig. 10. FTIR spectra of raw rice, roasted rice, flaked rice and roasted flaked rice

of raw rice and roasted rice had no major changes in spectral region from $721.89 \mathrm{~cm}^{-1}$ to $2922.43 \mathrm{~cm}^{-1}$ band. The band range $1744.14-1743.85 \mathrm{~cm}^{-1}$ revealed the presence of free fatty acids in raw rice, roasted rice, flaked rice and roasted flaked rice the similar result was also observed [60]. The absorption band observed at wave number $2854.65 \mathrm{~cm}^{-1}$ to $2926.01 \mathrm{~cm}^{-1}$ represented the symmetrical and asymmetrical $-\mathrm{CH}_{2}$ - stretching band, whereas the band at $3621.23 \mathrm{~cm}^{-1}$ to $3803.84 \mathrm{~cm}^{-1}$ wave number were related to $-\mathrm{O}-\mathrm{H}$ bond stretching in roasted flaked rice [61]. The bands at $759.95-707.88 \mathrm{~cm}^{-1}$ in finger print region of raw rice, roasted rice, flaked rice and roasted flaked rice indicated the $\alpha$-linkage in starch [62]. The shift of band from $1658 \mathrm{~cm}^{-1}$ wave number during the processing showed $7 \mathrm{~cm}^{-1}$ and $17 \mathrm{~cm}^{-1}$ shift towards lower wave number in roasted rice and flaked rice sample, respectively. The band at $3387 \mathrm{~cm}^{-1}$ showed antagonistic behaviour with respect to the above mentioned band and increase in higher wave number 13 and $27 \mathrm{~cm}^{-1}$ for roasted rice and flaked rice. In roasted flaked rice band at 3803.84 and $3621.23 \mathrm{~cm}^{-1}$ wave number the $\mathrm{O}-\mathrm{H}$ stretching was found. All the characteristics bands compared to raw rice showed that there was some degree of modification in chemical structure (stretching of band). During processing of roasted flaked rice no major difference was obtained in bands as shown in IR spectrum [63]. The transmittance of the raw rice was lower than the values obtained from roasted rice, 
flaked rice and roasted flaked rice, showing a slight difference and the latter depicting a dramatic increase in the transmittance (Fig. 10). Band ratio of the intensities of two bands (1082.07 and $1022.27 \mathrm{~cm}^{-1}$ ) in all sample represented crystalline character, but the highest crystallinity was found in raw rice $[63,64]$.

X-ray diffraction (XRD): X-ray powder diffraction is a rapid analytical technique which is used for phase identification of crystalline materials and can provide information of unit cell dimensions. X-ray diffractogram and relative crystallinity of raw, roasted, flaked and roasted flaked rice are presented (Fig. 11). The amorphous lamellas and semi-crystalline lamellas of starch granules allocated in the endosperm of rice kernel are responsible for the occurrence of diffraction peaks. Based on X-ray diffraction pattern starches are classified in three types such as A, B and C. A-type is common for cereal starches i.e. rice, wheat, maize and B-type is typical for tubers and amylose rice cereal starches. Whereas, $\mathrm{C}$-type is a mixture of $\mathrm{A}$ and $\mathrm{B}$ patterns, which is commonly found in leguminous starches $[65,66]$. V-type is another type of starch formed on forming the complex between amylose and a complexing functional group such as iodine, alcohol, cyclohexane, fatty acids, protein, etc. Analyzing the X-ray diffraction pattern of raw, roasted, flaked and roasted flaked rice (Fig. 11) revealed that the prominent peak angle $(2 \theta)$ for the raw rice was observed

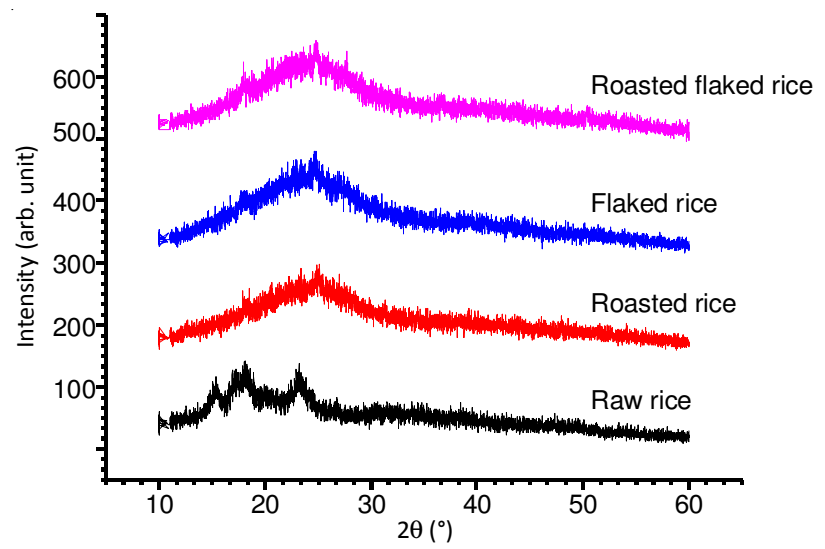

Fig. 11. X-ray diffraction pattern of raw rice (A), roasted rice (B), flaked rice $(\mathrm{C})$ and roasted flaked

at $15^{\circ}, 17^{\circ}, 18^{\circ}$ and $23^{\circ}$ showed the similarity with A-type pattern. The right shift with broadening of peak on roasting of paddy confirms the conversion of crystalline structure of rice to the amorphous structure with the simultaneous reduction in the particle size. Further, flaking process compresses the material between the rollers of edge runner leading to the further conversion to some extent the enlargement of particle supported with the increase in resistant starch content [23] (Table-1).
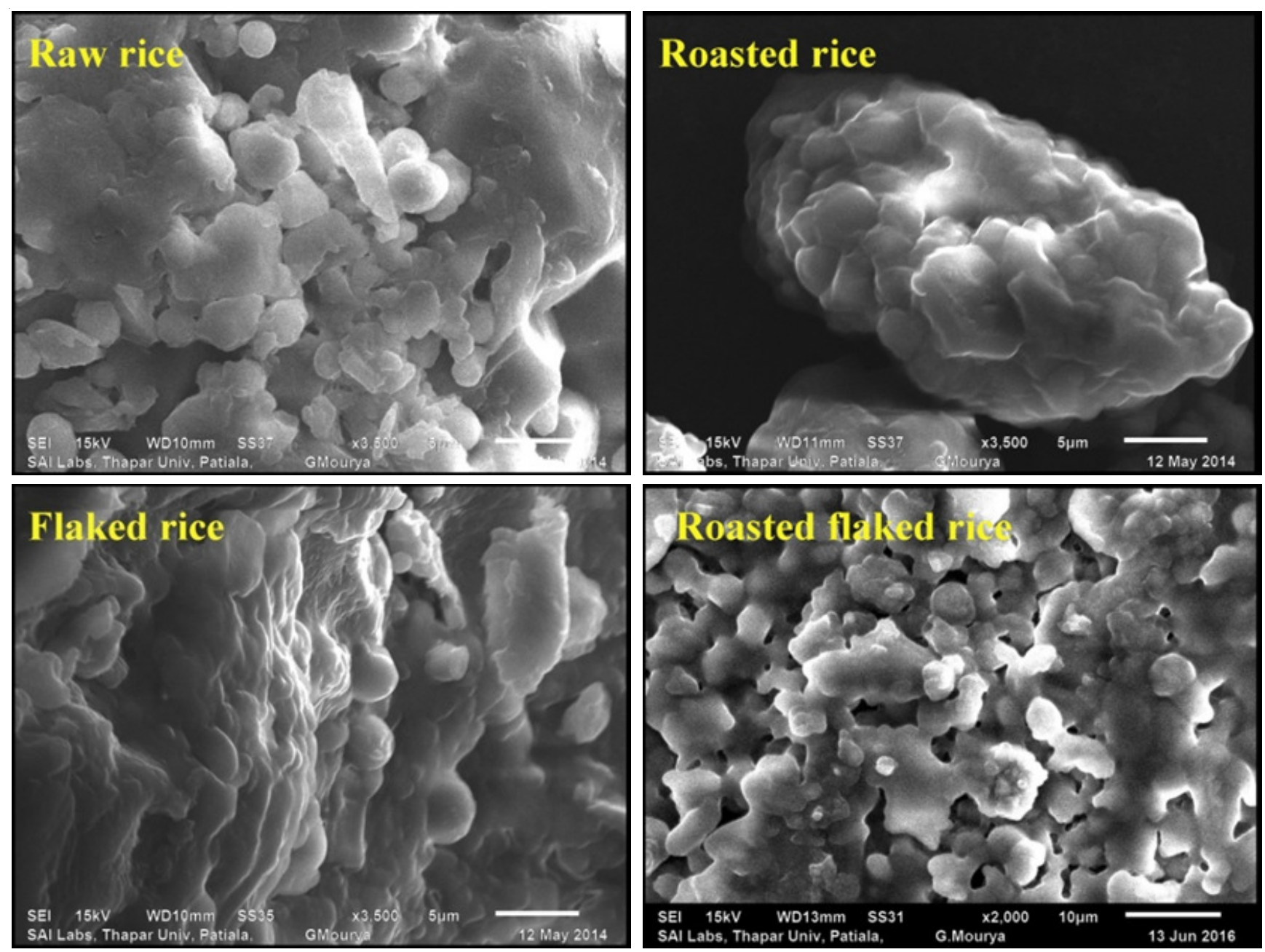

Fig. 12. Scanning electron micrographs (SEM) of roasted flaked rice on different levels of processing 
Microstructure: Scanning electron microscopy (SEM) is a technique which gives information about the external morphology and microstructure [28]. Morphological features at micro level of raw rice, roasted rice, flaked rice and roasted flaked rice were found to vary from each other (Fig. 12). Hexagonal having smooth surface, globular and polygonal shapes is found to be associated with the starch granules of raw rice. During roasting of soaked paddy, there was swelling, gelatinization and agglomeration of starch granules (Fig. 12) due to effect of heat treatment on moist starch granules during roasting of soaked paddy in hot sand for 28-30 s. Starch granules of flaked rice were found smaller in size having compacted granules resulted from the mechanical compressing force applied during the process of flaking. Application of high temperature during roasting at first starch granules gets gelatinized followed expansion forming the continuous and denser structure (Fig. 12).

\section{Conclusion}

Properties of flaked rice and roasted flaked rice affected by level of processing and dependent on the extent of roasting temperature and time. Response surface methodology could successfully be applied for the optimization of process parameters for the development of roasted flaked rice. Use of 302 ${ }^{\circ} \mathrm{C}$ temperature and $41 \mathrm{~s}$ duration is thus recommended to get the highly acceptable roasted flaked rice. The substantial increase in the resistant starch further adds the additional attraction to use the roasted flaked rice as the important functional ready to use raw material in the manufacture of convenience cereal breakfast item.

\section{ACKNOWLEDGEMENTS}

The first author (SK) is thankful to University Grant Commission, New Delhi, India for providing financial assistance in the form of Rajiv Gandhi National fellowship (RGNF-201213). The authors are thankful to Anand Agriculture University, Anand, India for providing paddy variety (Gurjari) for research work and also grateful to Balatripura Agro Industries, Ahmadabad, India for facilitating the development of flaked rice.

\section{REFERENCES}

1. FAOSTAT, http://faostat.fao.org/beta/en/\#data/QC (2016).

2. K. Prasad and Y. Singh, Rice Based Vegetable Supplemented Functional Instant Soup Mix: Development and Optimization, Scholars' Press, Germany (2014).

3. K. Prasad, P. Prakash and K.K. Prasad, Indian J. Gastroenterol., 26, 123 (2007)

4. K. Prasad, P. Prakash and K.K. Prasad, World J. Dairy Food Sci., 5, 164 (2010)

5. K. Prasad, P. Prakash and K.K. Prasad, Rice Based Functional Cookies for Celiac: Studies on its Formulation, Lambert Academic Publishing, Germany (2010)

6. K.M. Sahay and K.K. Singh, Unit Operations of Agricultural Processing, Vikas Publishing House Pvt. Ltd., New Delhi, India (2007).

7. N.N. Mohsenin, Physical Properties of Plant and Animal Materials, Gordon and Breach Science, New York (1970).

8. T. Bhatia, R.K. Sharma, R. Kumar and K. Prasad, Res. Rev. Biosci., 3 153 (2010)

9. P.N. Ghadge and K. Prasad, J. Food Process. Technol., 3, 175 (2012); https://doi.org/10.4172/2157-7110.1000175.

10. R. Haq, M. Wani and K. Prasad, Cogent Food Agric., 2, 1133371 (2016).

11. V. Kaushik, H.K. Sharma, K. Prasad and M.B. Bera, J. Ind. Pollut. Contr., 17, 201 (2001).
12. K. Prasad, A. Anil, Y. Singh and A.S.K. Sinha, Int. Food Res. J., 20, (2013).

13. Y. Singh and K. Prasad, ORYZA-An Int. J. Rice, 50, 174 (2013).

14. Y. Singh and K. Prasad, J. Food Measur. Charact., 10, 80 (2016); https://doi.org/10.1007/s11694-015-9279-7.

15. Y.S. Yadav and K. Prasad, Agric. Mechan. Asia, Africa Latin Am., 47, 56 (2016).

16. Y. Singh and K. Prasad, Pertanika J. Trop. Agric. Sci., 37, 331 (2014).

17. J.K. Buggenhout, K. Brijs, I. Celus and J.A. Delcour, J. Food Eng., 117, 304 (2013); https://doi.org/10.1016/j.jfoodeng.2013.03.009.

18. Y. Singh, P. Yadav and K. Prasad, Asian J. Chem., 26, 1145 (2014); https://doi.org/10.14233/ajchem.2014.16046.

19. B.S. Luh, Rice Production, Van Nostrand Reinhold, New York, vol. I (1991).

20. W.E. Marshall and J.I. Wadsworth, Rice Science and Technology, Madison Avenue, New York (1994).

21. G. Deepa, V. Singh and K.N. Naidu, Food Chem., 106, 165 (2008); https://doi.org/10.1016/j.foodchem.2007.05.062.

22. K. Prasad, Y. Singh and A. Anil, J. Trop. Agric. Food Sci., 40, 193 (2012).

23. S. Kumar, R.-U. Haq and K. Prasad, J. Saudi Soc. Agric. Sci.; https://doi.org/10.1016/j.jssas.2016.05.004.

24. S. Soponronnarit, A. Nathakaranakule, A. Jirajindalert and C. Taechapairoj, J. Food Eng., 75, 423 (2006); https://doi.org/10.1016/j.jfoodeng.2005.04.058.

25. S. Kumar and K. Prasad, Int. J. Agric. Food Sci. Technol., 4, 765 (2013).

26. R.C. Mujoo, A. Chandrashekar and S.Z. Ali, J. Cereal Sci., 28, 187 (1998); https://doi.org/10.1006/jers.1998.0199.

27. R.L. Heiniö, M.W.J. Noort, K. Katina, S.A. Alam, N. Sozer, H.L. de Kock, M. Hersleth and K. Poutanen, Trends Food Sci Technol., 47, 25 (2016); https://doi.org/10.1016/j.tifs.2015.11.002.

28. C.L. Mahanta and K.R. Bhattacharya, J. Food Sci. Technol., 47, 182 (2010); https://doi.org/10.1007/s13197-010-0038-9.

29. M. Chitra, V. Singh and Z.S. Ali, J. Food Sci. Technol., 47, 414 (2010); https://doi.org/10.1007/s13197-010-0068-3.

30. J.A. Mir, K. Srikaeo and J. Garcia, Int. Food Res. J., 20, 1329 (2013).

31. AOAC, Association of Official Analytical Chemists Official Methods of Analysis. AOAC, Washington, USA (2002).

32. S. Ranganna, Handbook of Analysis of Quality Control of Fruit and Vegetable Product, Tata McGraw-Hill, New Delhi, India (2000).

33. S.K. Thimmaiah, Standard Methods of Biochemical Analysis. Kalayani, New Delhi, India (1999).

34. L. Wang and Y.J. Wang, J. Cereal Sci., 39, 291 (2004); https://doi.org/10.1016/j.jcs.2003.11.002.

35. J.W. White, J. Ass. Off. Anal. Chem., 62, 205 (1979).

36. K. Prasad, P.R. Vairagar and M.B. Bera, Food Res. Int., 43, 483 (2010); https://doi.org/10.1016/j.foodres.2009.09.038.

37. T. Bhatia, R.K. Sharma and K. Prasad, Asian J. Chem., 21, 103 (2009).

38. P.N. Ghadge, P.R. Vairagar and K. Prasad, Agric. Eng. Int.: The CIGR E-J., 10 (FP 07 039) (2008)

39. K. Prasad and R.K. Sharma, Indian J. Agric. Res., 46, 199 (2012).

40. Ankita and K. Prasad, Der Pharm. Lett., 7, 269 (2015).

41. J.W. Rhim, C.L. Wu, C.L. Weller and M. Schnepf, J. Food Sci., 64, 149 (1999) https://doi.org/10.1111/j.1365-2621.1999.tb09880.x.

42. C.L. Hsu and Y. Chen, Food Chem., 83, 85 (2003); https://doi.org/10.1016/S0308-8146(03)00053-0.

43. V. Stojceska, P. Ainsworth, A. Plunkett, E. Ibanoglu and S. Ibanoglu, J. Food Eng., 87, 554 (2008); https://doi.org/10.1016/j.jfoodeng.2008.01.009.

44. S. Maisont and W. Narkrugsa, Witthayasan Kasetsat Witthayasat, 44, 251 (2010).

45. K. Prasad and N. Nath, J. Dairy. Foods Home Sci., 30, 278 (2011)

46. H.K. Sharma, K. Prasad, S. Jindal, P. Sood and H. Pandey, Int. J. Dairy Technol., 56, 22 (2003); https://doi.org/10.1046/j.1471-0307.2003.00069.x.

47. L.S. Badwaik, K. Prasad and S.C. Deka, Int. Food Res. J., 19, 341 (2012).

48. T.R. Kukreja, D. Kumar, K. Prasad, R.C. Chauhan, S. Choe and P.P. Kundu, Eur. Polym. J., 38, 1417 (2002); https://doi.org/10.1016/S0014-3057(02)00005-8.

49. V. Kumar, H.K. Sharma and K. Prasad, Ecol. Environ. Conserv., 14, 95 (2008). 
50. K. Kumari, K. Prasad and P.P. Kundu, Express Polym. Lett., 3, 207 (2009); https://doi.org/10.3144/expresspolymlett.2009.27.

51. K. Prasad and N. Nath, Sugar Technol., 4, 109 (2002); https://doi.org/10.1007/BF02942691.

52. K. Prasad and H.K. Sharma, Asian J. Chem., 13, 1489 (2001).

53. K. Prasad and H.K. Sharma, Egyptian J. Dairy Sci., 30, 75 (2002).

54. K. Prasad and P.R. Vairagar, Instant Chickpea Splits: Optimization using Response Surface Methodology, Lambert Academic Publishing, Germany (2014).

55. K. Prasad, Int. J. Appl. Agric. Res., 4, 87 (2009).

56. K. Prasad and N. Nath, Asian J. Chem., 14, 723 (2002).

57. E.B. Filmore, A. Kramer and K. Gerald, System Analysis for the Food Industry, AVI, Westport, Connecticut (1976).

58. A.M. Joglekar and A.T. May, in eds.: E. Graf and I.S. Saguy, Food Product Development from Concept to the Market Place, AVI, Westport, Connecticut (1991).

59. R.G. Henika, Food Technol., 36, 96 (1982).
60. R.R. Gangidi, A. Proctor and J.F. Meullenet, J. Am. Oil Chem. Soc., 79, 7 (2002); https://doi.org/10.1007/s11746-002-0427-4.

61. A. Dogan, G. Siyakus and F. Severcan, Food Chem., 100, 1106 (2007); https://doi.org/10.1016/j.foodchem.2005.11.017.

62. V. Singh and K. Kumari, Int. J. Mater. Bio. Appl., 4, 7 (2014).

63. H. Dutta and C.L. Mahanta, Food Res. Int., 49, 655 (2012); https://doi.org/10.1016/j.foodres.2012.09.014.

64. J.J.G. van Soest, H. Tournois, D. de Wit and J.F.G. Vliegenthart, Carbohydr. Res., 279, 201 (1995); https://doi.org/10.1016/0008-6215(95)00270-7.

65. W. Shujun, Y. Jinglin and G. Wenyuan, Am. J. Biochem. Biotechnol., 1, 199 (2005). https://doi.org/10.3844/ajbbsp.2005.199.203.

66. S.W. Lee and C. Rhee, Food Res. Int., 40, 215 (2007); https://doi.org/10.1016/j.foodres.2006.05.005. 